\title{
Pengaruh Audit Tenure Terhadap Kualitas Audit pada Perusahaan Terbuka di Indonesia
}

\author{
Angela*, Marceline Miharja, Wijantini, Siti Farhana \\ Sekolah Bisnis dan Ekonomi, Departemen Akuntansi, Universitas Prasetiya Mulya
}

Keywords:

accrual discretionary, audit firm tenure, audit partner tenure, audit tenure, audit quality

Kata Kunci: akrual diskresioner, tenure KAP, tenure partner audit, tenure audit, kualitas audit

*Corresponding author: angela.hryn@student. pmsbe.ac.id

\begin{abstract}
This paper focuses on analyzing the effect of audit tenure on firm and audit partners on audit quality in non-financial publicly listed companies in Indonesia in the period of 2008 until 2014. The research is motivated by the inconsistent results of previous research in Indonesia and also in other countries. The audit quality is measured by the absolute discretionary accrual proxy using the Modified Jones model (1995). Fundamentally, audit quality describes the results of the performance of independent auditor which is one form of monitoring cost on agency theory. The results show the negative significant relationship between audit firm tenure to audit quality, in line with research from Junaidi et al. (2012), among others. On the other hand, there was no significant relationship between audit partner tenure and audit quality, similar to research from Blandon \& Bosch (2017), among others. The result also supported by two types of robustness test. First, using the same model with different period has a negative significant result on audit firm tenure while there was no significant effect on audit partner tenure. Second robustness test using t-test for audit partner tenure on year 1 and 3, and the result shows there is no significant difference on audit quality. The result will be useful as consideration for regulators to concern more to the effect of audit firm tenure compared to tenure partner.
\end{abstract}

\section{Sari Pati}

Penelitian ini bertujuan untuk menganalisis pengaruh audit tenure pada KAP dan partner audit terhadap kualitas audit pada perusahaan terbuka non-keuangan di Indonesia pada periode 2008 hingga 2014. Motivasi penelitian ini disebabkan oleh hasil penelitian terdahulu yang masih inkonsisten baik di Indonesia maupun di negara lainnya. Kualitas audit diukur dengan proksi absolute discretionary accrual dengan menggunakan model Modified Jones (1995). Pada dasarnya, kualitas audit men ggambarkan hasil kinerja auditor independen yang merupakan salah satu bentuk dari monitoring cost pada teori keagenan. Hasil penelitian menunjukkan terdapat pengaruh negatif signifikan antara tenure KAP dengan kualitas audit sejalan dengan beberapa penelitian lain, diantaranya, Junaidi et al. (2012). Namun tidak terdapat pengaruh signifikan antara tenure partner audit dengan kualitas audit yang sejalan dengan beberapa penelitian lain, diantaranya, Blandon \& Bosch (2017). Diperkuat dengan dua hasil uji robustness, yang pertama menguji dengan dengan menggunakan periode 2008 hingga 2018 dan memiliki hasil negatif signifikan pada tenure KAP sedangkan tidak terdapat pengaruh signifikan pada tenure partner. Lalu pada uji robustness kedua dengan uji beda t-test terhadap kualitas audit pada tenure partner tahun 1 dan 3, dan memiliki hasil bahwa tidak terdapat perbedaan yang signifikan. Berdasarkan hasil penelitian ini, dapat menjadi pertimbangan bagi regulator unt uk lebih memperhatikan pengaruh tenure KAP dibandingkan tenure partner audit terhadap kualitas audit. 


\section{Pendahuluan}

Konflik kepentingan antara agent dan principal dapat didorong oleh asimetri informasi yang dapat terjadi karena manajemen memiliki informasi yang lebih mengenai keadaan perusahaan, namun belum tentu memberikan informasi keadaan bisnis yang sebenarnya kepada pemilik. Sehingga dibutuhkan keterbukaan informasi melalui laporan keuangan yang disajikan secara wajar, dapat dipercaya, dan dapat digunakan untuk pengambilan keputusan bagi penggunanya. Mengingat peran manajemen yang turut berperan dalam membuat laporan keuangan, tidak dapat menutup kemungkinan bahwa manajemen dapat melakukan manipulasi. Maka, dibutuhkan monitoring cost dalam bentuk jasa auditor publik independen yang dapat memastikan kredibilitas atas informasi di dalam laporan keuangan tersebut (Keune \& Johnstone, 2012). Namun, peran auditor eksternal mulai menjadi perdebatan semenjak munculnya skandal besar seperti Enron, Lehman Brothers, serta Kimia Farma.

Dengan adanya kasus tersebut maka dibentuk “The Sarbanes-Oxley Act of 2002” di Amerika yang juga diadaptasi di Indonesia dengan pembentukan KMK Nomor 423/KMK.06/2002 yang mengatur mengenai independensi dengan cara membatasi jangka waktu hubungan antara klien dengan auditor yang sama, yang disebut audit tenure (baik kantor akuntan publik maupun audit partner) untuk mencegah adanya kecurangan (Mansi, Maxwell \& Miller, 2004). Audit tenure yang panjang dapat meningkatkan kompetensi namun juga dapat menurunkan tingkat independensi auditor. Pengaruh audit tenure dapat tergambar melalui kualitas audit yang dihasilkan dalam bentuk laporan keuangan, karena kualitas audit juga didasarkan oleh faktor kompetensi auditor dalam menemukan salah saji yang material dan faktor independensi auditor untuk bisa melaporkan kesalahan tersebut (DeAngelo, 1981).

Terdapat hasil yang mendukung semakin lama audit tenure akan meningkatkan kompetensi (Geiger \& Raghunandan, 2002; Johnson, Khurana \& Reynolds, 2002; Carcello \& Nagy, 2004) karena dengan audit tenure yang lebih lama akan memiliki pengetahuan yang mendalam akan bisnis dan industri perusahaan sehingga audit menjadi berkualitas dan lebih efisien. Sedangkan pada penelitian 
lainnya, dengan audit tenure yang lebih relatif lama akan memberikan peningkatan pada hubungan yang akrab antara anggota staf audit dan bagian internal perusahaan sehingga memungkinkan terjadinya penerimaan atas segala upaya perusahaan untuk melakukan manipulasi dan dapat menggambarkan kualitas yang lebih rendah dan audit yang kurang efisien (Defond \& Subramanyam, 1998; Siregar, Amarullah,Wibowo \& Anggraita, 2012). Hasil dari penelitian ini menggambarkan bahwa audit firm tenure memiliki pengaruh negatif terhadap kualitas audit, namun audit partner tenure tidak memiliki pengaruh. Didukung juga dengan hasil uji robustness dengan periode yang lebih panjang memiliki hasil yang sama, dan dengan uji t-test menunjukkan tidak adanya perbedaan kualitas audit antara audit partner tenure.

Melihat pada hasil inkonklusif pada penelitian-penelitian terdahulu baik di luar negeri maupun di Indonesia mengenai hubungan audit tenure dengan kualitas audit, penelitian ini masih menarik untuk diteliti kembali pengaruh faktor independensi terhadap kualitas audit akibat adanya audit tenure yang panjang untuk membuktikan hubungan yang terjadi antara audit tenure terhadap kualitas audit. Perbedaan penelitian ini dengan penelitian yang lain ada pada objek yang diteliti dengan mendalami peranan dari masing-masing variabel audit tenure, sehingga dapat menganalisa peran masing-masing audit tenure baik dari firm dan partner terhadap kualitas audit. Sehingga dapat juga menganalisa apakah pembatasan audit tenure pada firm dan partner dapat membuat kegiatan monitoring menjadi lebih efektif. Untuk periode penelitian utama akan dilakukan dengan sampel dimulai tahun 2008 sebagai batas awal dengan diterapkannya penerapan Peraturan Menteri Keuangan No. 17/PMK.01/2008, hingga tahun 2014 sebagai batas akhir sebelum diterapkannya Peraturan Pemerintah Republik Indonesia nomor 20 tahun 2015 tentang Praktik Akuntan Publik. 


\section{Telaah Literatur dan Pengembangan Hipotesis}

\section{Teori Keagenan}

Teori yang dirumuskan oleh Jensen dan Meckling (1976) menjelaskan hubungan keagenan dalam teori keagenan bahwa perusahaan memiliki kumpulan hubungan kontraktual (nexus of contract) antara manajer (agent) dan pemilik (principal). Walaupun berada dalam 1 perusahaan yang sama, namun kedua pihak tersebut dapat memiliki perbedaan kepentingan dan tujuan sehingga pada akhirnya akan muncul konflik yang disebut sebagai permasalahan agensi (agency problem). Permasalahan agensi dapat terbagi menjadi 3 tipe, tipe 1 (pemilik dan manajemen), tipe 2 (pemegang saham mayoritas dan minoritas), dan tipe 3 (kreditur dan manajemen). Terfokuskan pada permasalah tipe 1 yang terjadi di antara pemilik dan manajemen pada dasarnya didasarkan oleh adanya pembagian kontrol dalam suatu perusahaan (Berle \& Means, 1932 dalam Panda \& Leepsa, 2017). Manajer akan diberikan wewenang untuk dapat menjalankan perusahaan sesuai dengan kepentingan dari owner, namun pada keadaan tertentu, manajer juga ingin memaksimalkan keuntungan pribadi yang berbeda dari kepentingan owner contohnya untuk memaksimalkan kompensasi dengan berlandaskan pada rasionalisasi atas tingkah laku manusia manusia (Sen, 1987; Wiliamson, 1985 dalam Panda \& Leepsa, 2017).

Untuk bisa meminimalisir kemungkinan terjadinya permasalahan tersebut, maka akan muncul biaya agensi yang ditanggung principal maupun agent (Jensen \& Meckling, 1976). Dalam buku Godfrey, Hodgson, Tarca, Hamilton dan Holmes (2010) membagi biaya agensi menjadi tiga, yaitu monitoring cost, bonding cost, dan residual loss. Monitoring cost adalah biaya untuk melakukan pengawasan dan menilai perilaku agent dengan cara mengukur, mengamati, dan mengontrol. Salah satu contoh monitoring cost adalah biaya penggunaan jasa auditor eksternal untuk menilai kewajaran laporan keuangan perusahaan. Sedangkan bonding cost merupakan biaya yang ditanggung oleh agent untuk menetapkan mekanisme yang dapat menunjukkan bahwa agent bertindak sesuai dengan 
kepentingan principal. Selain itu terdapat residual loss yang merupakan kerugian yang harus ditanggung akibat pengambilan keputusan manajemen yang tidak sesuai dengan kepentingan untuk maksimalisasi keuntungan principal.

\section{Audit Tenure}

Audit tenure merupakan lamanya waktu dalam hubungan auditor dengan klien, hubungan tersebut dilihat dari lamanya tahun buku laporan keuangan yang diaudit oleh auditor tersebut (Johnson et al., 2002). Di Indonesia, peraturan pembatasan masa pemberian jasa audit yang pertama adalah KMK Nomor 423/KMK.06/2002. Kemudian peraturan tersebut mengalami perubahan pada tahun 2003, 2008, dan 2015. Terdapat perbedaan peraturan Peraturan Menteri Keuangan No. 17/PMK.01/2008 dan Peraturan Pemerintah Republik Indonesia Nomor 20 Tahun 2015, yaitu pada peraturan tahun 2008 pembatasan masa pemberian jasa audit oleh KAP dibatasi selama 6 (enam) tahun buku berturut-turut dan oleh seorang akuntan publik dan 3 (tiga) tahun buku berturut-turut oleh akuntan publik kepada klien yang sama, serta akuntan publik dan KAP dapat menerima kembali penugasan setelah satu tahun buku tidak memberikan jasa audit kepada klien tersebut. Sedangkan pada Peraturan Pemerintah Republik Indonesia Nomor 20 Tahun 2015 sudah tidak membatasi masa pemberian jasa audit oleh KAP dan untuk akuntan publik diperpanjang menjadi 5 (lima) tahun buku berturut-turut, dan penugasan kembali dalam dilakukan setelah 2 (dua) tahun buku.

Semakin panjang audit tenure, dapat mempengaruhi dua faktor yang akhirnya juga memberikan pengaruh pada tingkat kualitas audit, yaitu faktor independensi dan kompetensi (DeAngelo, 1981). Ditinjau dari faktor independensi, dengan semakin lama audit tenure dapat membentuk hubungan secara emosional terhadap klien dan mengakibatkan independensi menjadi menurun sehingga akan tercermin pada pembuatan asumsi oleh auditor yang kurang objektif (Dinuka \& Zulaikha, 2014). Selain itu, masa perikatan audit yang panjang akan menimbulkan adanya potensi 
untuk membangun ikatan dari segi ekonomi, dan auditor menjadi akan menyetujui upaya klien dalam melakukan rekayasa pada laporan keuangan mela lui teknik akuntansi (Nasser, Wahid, Nazri \& Hudaib, 2006). Dari sisi auditor, jika klien yang diaudit sudah memiliki kontrol pada laporan keuangan yang baik dan manajemen klien tersebut memiliki integritas dan kompetensi yang baik, terdapat kecenderungan auditor memiliki ekspektasi bahwa klien akan terus memiliki atribut tersebut, dan hal tersebut membuat sikap skeptis dari auditor menjadi semakin berkurang (Carcello \& Nagy, 2004).

Sedangkan jika dilihat dari faktor kompetensi, semakin lama audit tenure dapat meningkatkan pengetahuan mengenai spesifik industri dan informasi spesifik klien seperti dalam hal proses bisnis, sistem akuntansi, dan internal kontrol, sehingga dengan pengetahuan tersebut dapat meningkatkan kompetensi auditor untuk mendeteksi material misstatement pada laporan keuangan (Johnson et al., 2002). Namun, jika terdapat pergantian auditor maka pengetahuan spesifik mengenai klien menjadi terbatas pada auditor yang baru (DeAngelo, 1981). Dan proses untuk memahami spesifik industri dan perusahaan klien membutuhkan waktu setidaknya satu tahun setelah pergantian auditor (Knapp, 1991 dalam Krauss \& Zulch, 2013). Oleh karena itu, terlihat terdapat dua pandangan mengenai pengaruh dari panjang nya audit tenure. Maka, sesuai tujuan penelitian, akan lebih fokus terhadap pengaruh audit tenure terhadap tingkat independens i yang kemudian dapat mempengaruhi tingkat kualitas audit.

\section{Independensi dan Kualitas Audit}

Kualitas audit diartikan sebagai "the market-assessed joint probability that an auditor will both detect and report material misstatements" yaitu penggabungan probabilitas kemampuan auditor untuk mendeteksi material misstatement pada laporan keuangan dan pada sistem akuntansi di suatu perusahaan serta probabilitas melaporkan penemuan material misstatement tersebut (DeAngelo, 1981). Probabilitas seorang auditor dapat menemukan suatu kesalahan bergantung pada kemampuan auditor, prosedur audit, tingkat penarikan sampel, dan faktor lainnya. Sedangkan probabilitas auditor 
melaporkan kesalahan tersebut bergantung pada independensi auditor terhadap klien. Secara profesi, auditor memiliki tujuan untuk memastikan angka dari laporan keuangan yang disajikan sudah cukup mewakili dan menggambarkan keadaan operasional dan keuangan perusahaan yang sebenarnya. Sehingga dari profesi tersebut menunjukkan bahwa faktor independensi sangat dibutuhkan agar menghasilkan laporan keuangan yang dapat dipercaya dan memiliki kualitas audit yang baik.

Pengukuran tinggi atau rendahnya kualitas audit dapat diukur dengan kualitas laba (earning quality). Laporan keuangan yang memiliki kualitas audit yang baik, menunjukkan laporan keuangan tersebut memiliki keakuratan isi yang dapat merefleksikan hasil kinerja dan keadaan keuangan perusahaan sebenarnya (Chen, Lin \& Lin, 2008). Sehingga kualitas laba yang disajikan dalam laporan keuangan merefleksikan kualitas dari auditor da lam melakukan audit (Chen et al., 2008). Namun, laba pada dasarnya terdiri dari dua elemen yaitu akrual dan arus kas, dan khususnya pada akrual nondiskresioner yang merupakan penyesuaian terhadap arus kas yang dipilih oleh manajemen untuk mempengaruhi laba perusahaan (Healy, 1985 dalam Siregar et al., 2012), terdapat kesempatan bagi manajemen untuk dapat melakukan kecurangan (Achmad, et al., 2007). Sehingga dengan tingkat akrual diskresioner yang tinggi dapat menunjukkan kualitas laba yang rendah (Chen et al., 2008). Lalu sehubungan dengan kualitas laba (earning quality) yang menjadi proksi dari kualitas audit, maka dengan kualitas laba yang rendah menunjukkan kualitas audit yang rendah.

Terdapat dua alasan yang melatarbelakangi penggunaan akrual diskresioner sebagai proksi kualitas audit. Yang pertama, meskipun terdapat beberapa proksi kualitas audit pada penelitian serupa dengan proksi selain nilai akrual diskresioner, seperti opini going concern, namun pemberian opini audit juga terkandung adanya faktor subjektivitas serta terdapat kasus opinion shopping. Sehingga perusahaan dapat memiliki opini wajar tanpa pengecualian meskipun di dalam laporan keuangan tersebut tetap terkandung banyak error dalam bentuk akrual diskresioner seperti pada kasus Enron, WorldCom, dan Kimia Farma pada tahun 2002 (Rusmanto, Djamil \& Salim, 2014). Lalu yang kedua 
adalah mengenai fokus penelitian ini untuk menguji pengaruh panjangnya audit tenure terhadap tingkat independensi auditor yang akhirnya mempengaruhi kualitas audit. Oleh karena itu, dilihat dari faktor independensi yang menurun dapat membuat auditor cenderung untuk tidak membatasi adanya kesalahan pada laporan keuangan, yang salah satunya dapat tercermin dari tingkat akrual diskresioner yang tinggi namun tidak dilimitasi dan menyebabkan kualitas audit yang menurun.

Dengan adanya penggunaan akrual diskresioner yang dijadikan proksi dalam mengukur kualitas audit maka akan tergambar hubungan negatif atau berkebalikan, sehingga jika nilai akrual diskresioner tinggi atau besar maka kualitas audit rendah dan sebaliknya.

\section{Pengembangan Hipotesis}

Semenjak munculnya keterlibatan auditor dalam skandal praktik kecurangan akuntansi, khususnya dalam memanipulasi laporan keuangan, peran dari auditor eksternal pun masih menjadi perdebatan. Dengan adanya hubungan yang terbentuk antara klien dan akuntan publik, ataupun disebut tenure, dapat mempengaruhi independensi dan objektivitasnya dalam meninjau laporan keuangan. Pada dasarnya, auditfirm tenure maupun audit partner tenure yang terlalu lama dapat memberikan pengaruh kepada kualitas audit, terlebih pada faktor independensi. Dengan audit tenure yang panjang pada akhirnya akan menimbulkan "excessive familiarity" dan mempengaruhi auditor saat pembuatan judgement. Selain itu, akan ada kecenderungan bagi auditor untuk bisa mempertahankan klien yang cukup besar untuk membuat reputasi auditor menjadi lebih baik ataupun terkait dengan fee yang akan diterima.

Namun, dari sisi praktisi berpendapat bahwa dengan adanya audit tenure yang panjang dapat meningkatkan kompetensi, karena dapat meningkatkan pengetahuannya pada industri spesifik dan sudah mengenal klien secara spesifik sehingga dapat lebih mudah mendeteksi adanya kegiatan yang tidak reguler terjadi atau adanya ketidaksesuaian kinerja laporan keuangan dengan keadaan industri. 
Sehingga dengan memiliki kompetensi yang tinggi dapat meningkatkan kualitas audit. Selain itu, dari sisi manajemen (klien) juga mempertimbangkan waktu dan biaya yang dibutuhkan untuk memilih auditor baru dan memberikan informasi kepada auditor yang baru mengenai industri dan keadaan internal klien.

Secara khusus pada audit firm tenure dengan mempertimbangkan faktor independensi, terdapat beberapa penelitian yang menghasilkan jawaban yang serupa sesuai dengan konsep yaitu pada penelitian Al-Thuneibat et al. (2011), Junaidi et al. (2012), serta Panjaitan dan Chariri (2014), menggambarkan bahwa audit firm tenure memiliki pengaruh negatif terhadap kualitas audit dan menggambarkan bahwa hubungan yang dekat di antara auditor dengan klien akan mempengaruhi integritas dan independensi auditor sehingga pada akhirnya akan membuat kualitas audit menjadi menurun. Berdasarkan pada konsep dan penelitian tersebut maka hipotesis yang dapat dirumuskan adalah sebagai berikut:

\section{H1 : Audit firm tenure berpengaruh negatif terhadap kualitas audit}

Audit tenure juga dapat dilihat dari segi audit partner tenure. Berfokus pada konsep independensi, , pada penelitian Carey \& Simnett (2006), Siregar et al. (2012), juga menggambarkan hal yang serupa. Dengan adanya audit partner tenure yang semakin lama maka objektivitas auditor dalam melakukan audit laporan keuangan akan mengikuti keinginan klien dengan adanya harapan apabila segalanya sesuai dengan harapan klien, klien akan terus mempertahankan auditor yang sama. Tentunya hal ini akan memberikan dampak yang menguntungkan bagi auditor terutama apabila perusahaan klien merupakan perusahaan yang besar dan dapat memberikan manfaat, baik dari segi reputasi dan ekonomis. 
Berdasarkan pada konsep dan hasil pene litian diatas, maka hipotesis yang dapat dirumuskan mengenai pengujian hubungan audit partner tenure terhadap kualitas audit dengan mempertimbangkan faktor independensi dapat dirumuskan sebagai berikut:

\section{H2 : Audit partner tenure berpengaruh negatif terhadap kualitas audit}

\section{Kerangka Penelitian}

Mengacu pada telaah literatur dan pengembangan hipotesis yang sudah dijabarkan di atas, maka kerangka pemikiran untuk menguji hipotesis dapat ditunjukkan sebagai berikut:

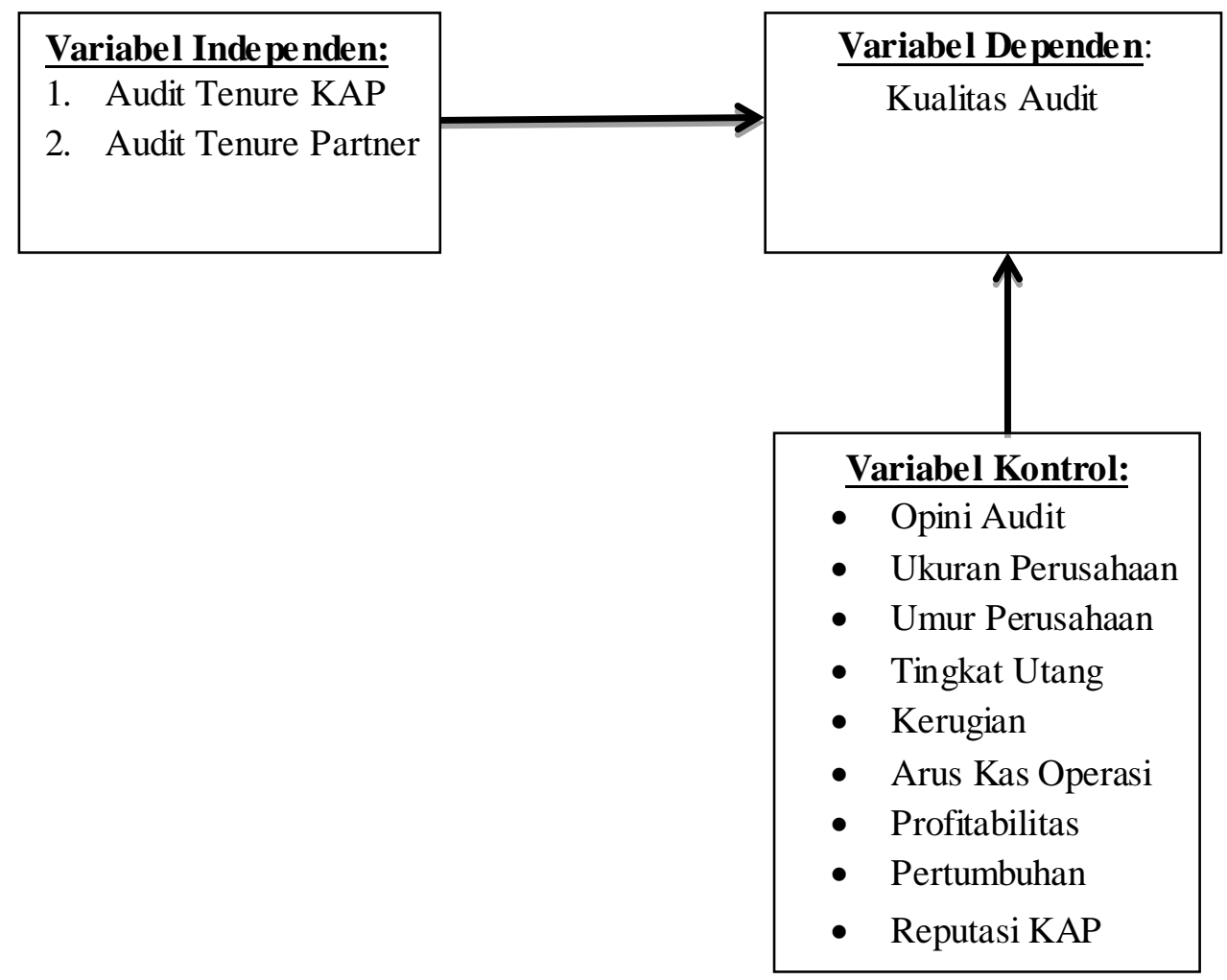

Gambar 1. Ke rangka Penelitian 


\section{Metode Penelitian}

\section{Populasi dan Sampel}

Penelitian utama untuk menguji pengaruh audit tenure terhadap kualitas audit dalam melihat efektivitas pada Menteri Keuangan No. 17/PMK.01/2008 menggunakan data sekunder yang berasal dari laporan keuangan pada perusahaan terbuka di Indonesia yang telah terdaftar di Bursa Efek Indonesia (BEI) 2008 hingga 2014 yang diperoleh dari S\&P Capital IQ, yang dilengkapi melalui website perusahaan. Adapun data sampel penelitian pada masing - masing hipotesis dapat dirincikan sebagai berikut:

Tabel 1. Pe rolehan Sampel Penelitian

\begin{tabular}{|c|c|c|c|c|}
\hline \multirow[t]{2}{*}{ Pemilihan Sampel } & \multicolumn{2}{|c|}{ Hipotesis 1} & \multicolumn{2}{|c|}{ Hipotesis 2} \\
\hline & $\begin{array}{c}\text { Jumlah } \\
\text { Perusahaan }\end{array}$ & $\begin{array}{c}\text { Juml ah } \\
\text { Observasi } \\
(2008-2014)\end{array}$ & $\begin{array}{c}\text { Jumlah } \\
\text { Perusahaan }\end{array}$ & $\begin{array}{c}\text { Juml ah Obser vasi } \\
(2008-2014)\end{array}$ \\
\hline Perusahaan tercatat di BEI & 634 & 4.438 & 634 & 4.438 \\
\hline Dikurangi : & & & & \\
\hline $\begin{array}{l}\text { Perusahaan yang termasuk } \\
\text { dalam industri finansial }\end{array}$ & $(123)$ & $(861)$ & $(123)$ & $(861)$ \\
\hline $\begin{array}{l}\text { Perusahaan tercatat di BEI } \\
\text { sejak tahun } 2008\end{array}$ & $(240)$ & $(1.680)$ & $(240)$ & $(1.680)$ \\
\hline $\begin{array}{l}\text { Perusahaan yang relisting } \\
\text { diantara tahun 2008-2014 }\end{array}$ & (6) & $(42)$ & (6) & $(42)$ \\
\hline $\begin{array}{l}\text { Perusahaan dengan data tidak } \\
\text { lengkap (data keuangan dan } \\
\text { nama KAP) sampai dengan } \\
2014\end{array}$ & (34) & $(238)$ & $(103)$ & $(721)$ \\
\hline Total sampel & 231 & 1.617 & 162 & 1.134 \\
\hline
\end{tabular}


Perbedaan dalam jumlah total sampel dikarenakan adanya 2 pengujian yang berbeda, pada $\mathrm{H} 1$ untuk melihat pengaruh tenure KAP terhadap kualitas audit dan $\mathrm{H} 2$ untuk melihat pengaruh tenure partner audit terhadap kualitas audit. Pada pengujian hipotesis 2 lebih banyak sampel perusahaan yang tidak memiliki kelengkapan data terutama terkait variabel tenure partner audit.

Dalam penelitian ini terdapat 2 hipotesis yang akan diuji sehingga akan menggunakan 2 model penelitian yang berbeda. Model penelitian untuk hipotesis 1, yaitu terdapat hubungan negatif antara audit firm tenure dengan kualitas audit adalah sebagai berikut :

$\mathrm{ABDA}_{\mathrm{i}, \mathrm{t}}=\alpha+\beta_{1}$ FTENURE $_{\mathrm{i}, \mathrm{t}}+\beta_{2}$ OPINION $_{\mathrm{i}, \mathrm{t}}+\beta_{3}$ SIZE $_{\mathrm{i}, \mathrm{t}}+\beta_{4} A G E_{\mathrm{i}, \mathrm{t}}+\beta_{5} L E V_{\mathrm{i}, \mathrm{t}}+\beta_{6} L_{\text {LSS }} \mathrm{PS}_{\mathrm{i}, \mathrm{t}}$ ${ }_{1}+\beta_{7} P E R F O R M_{\mathrm{i}, \mathrm{t}}+\beta_{8}$ CFO $_{\mathrm{i}, \mathrm{t}}+\beta_{9}$ GROWTH $_{\mathrm{i}, \mathrm{t}}+\beta_{10} R E P A F I R M_{\mathrm{i}, \mathrm{t}}+\varepsilon_{\mathrm{i}, \mathrm{t}}$

Model pene litian untuk hipotesis 2, yaitu terdapat pengaruh negatif antara audit partner tenure dengan kualitas audit adalah sebagai berikut :

$\mathrm{ABDA}_{\mathrm{i}, \mathrm{t}}=\alpha+\beta_{1}$ PTENURE $_{\mathrm{i}, \mathrm{t}}+\beta_{2}$ OPINION $_{\mathrm{i}, \mathrm{t}}+\beta_{3}$ SIZE $_{\mathrm{i}, \mathrm{t}}+\beta_{4} A G E_{\mathrm{i}, \mathrm{t}}+\beta_{5} L E V_{\mathrm{i}, \mathrm{t}}+\beta_{6} L_{\text {LSS }} \mathrm{i, \textrm {t } -}$ ${ }_{1}+\beta_{7}$ PERFORM $_{\mathrm{i}, \mathrm{t}}+\beta_{8} C F O_{\mathrm{i}, \mathrm{t}}+\beta_{9}$ GROWTH $_{\mathrm{i}, \mathrm{t}}+\beta_{10} R E P A F I R M_{\mathrm{i}, \mathrm{t}}+\varepsilon_{\mathrm{i}, \mathrm{t}}$

Keterangan :

$\mathrm{ABDA}_{\mathrm{i}, \mathrm{t}} \quad=$ Absolut akrual diskresioner (proksi kualitas audit)

FTENURE $_{\mathrm{i}, \mathrm{t}} \quad=$ Jumlah tahun berturut-turut suatu kantor akuntan publik melakukan audit pada perusahaan klien, dilihat dari nama lokal kantor akuntan publik

PTENURE $_{\mathrm{i}, \mathrm{t}} \quad=$ Jumlah tahun berturut-turut suatu partner auditor menandatangani laporan keuangan perusahaan klien

OPINION $_{\mathrm{i}, \mathrm{t}}=$ Opini audit $($ dummy, $1=$ qualified, $0=$ lainnya $)$

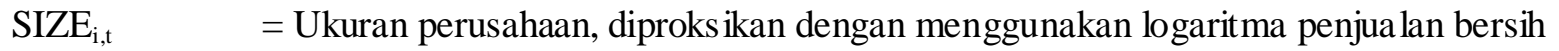

$\mathrm{AGE}_{\mathrm{i}, \mathrm{t}} \quad=$ Umur perusahaan sejak terdaftar di BEI

$\mathrm{LEV}_{\mathrm{i}, \mathrm{t}} \quad=$ Leverage, rasio liabilities-to-total asset

$\operatorname{LOSS}_{\mathrm{i}, \mathrm{t}-1} \quad=$ pendapatan yang negatif pada 1 tahun sebelumnya (dummy, 1 jika 
perusahaan tergolong rugi, 0 jika lainnya)

PERFORM $_{\mathrm{i}, \mathrm{t}} \quad=$ Profitabilitas, rasio pendapatan terhadap total aset

$\mathrm{CFO}_{\mathrm{i}, \mathrm{t}} \quad=$ Arus kas dari kegiatan operasi terhadap total aset

GROWTH $_{\mathrm{i}, \mathrm{t}} \quad=$ Peluang pertumbuhan perusahaan, diproksikan dengan pertumbuhan persentase penjualan dari tahun ke tahun

REPAFIRM $_{\mathrm{i}, \mathrm{t}}=$ Reputasi KAP, (dummy $1=$ non-Big 4, 0 = lainnya)

Untuk sampel $=$

$\mathrm{i}=$ perusahaan

$\mathrm{t}=$ tahun

\section{Ope rasiona lisasi Variabel}

Tabel 2. Tabel Ope rasionalisasi Variabel

\begin{tabular}{|c|c|c|c|c|}
\hline No. & Variabel & Definisi & Proksi & Sumber \\
\hline \multicolumn{5}{|c|}{ Variabel Inde penden } \\
\hline 1 & $\begin{array}{l}\text { Audit Firm Tenure } \\
\text { (FTENURE) }\end{array}$ & $\begin{array}{l}\text { Lamanya hubungan } \\
\text { antara kantor akuntan } \\
\text { publik dengan klien }\end{array}$ & $\begin{array}{l}\text { Jumlah tahun pengauditan kantor } \\
\text { auditor terhadap perusahaan; } \\
\text { kelompok } 1=\text { short term }=1-3 \\
\text { tahun, } \\
\text { Kelompok } 2=\text { medium term }=4-6 \\
\text { tahun, } \\
\text { Kelompok } 3=\text { long term }=>6 \\
\text { tahun }\end{array}$ & \multirow[t]{2}{*}{$\begin{array}{l}\text { Johnson, Khurana \& } \\
\text { Reynolds, } \\
\text { Geiger } \\
\text { Raghunandan (2002); } \\
\text { Chi \& Huang (2005); }\end{array}$} \\
\hline 2 & $\begin{array}{l}\text { Audit Partner } \\
\text { Tenure } \\
\text { (PTENURE) }\end{array}$ & $\begin{array}{l}\text { Lamanya hubungan } \\
\text { antara partner akuntan } \\
\text { publik dengan klien }\end{array}$ & $\begin{array}{l}\text { Jumlah tahun pengauditan partner } \\
\text { auditor terhadap perusahaan } \\
1=1 \text { tahun, } 2=2 \text { tahun, } 3=3 \\
\text { tahun, } 4=4 \text { tahun, dan } 5=5 \text { tahun }\end{array}$ & \\
\hline \multicolumn{5}{|c|}{ Variabel De penden } \\
\hline
\end{tabular}




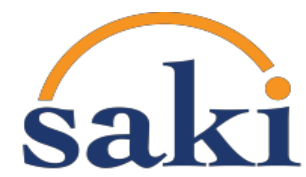

Studi Akuntansi dan Keuangan Indonesia | E-ISSN: 2654-6221

Studi Akuntansi \& Keuangan Indonesia

\begin{tabular}{|l|l|l|l|l|}
\hline 1 & Kualitas Audit & $\begin{array}{l}\text { Karakteristik atas hasil } \\
\text { audit berdasarkan } \\
\text { standar akuntansi dan } \\
\text { standar pengendalian } \\
\text { mutu }\end{array}$ & Akrual diskresioner (modified Jones & Dechow, Solan \& \\
Sweeney (1995)
\end{tabular}


Tabel 2. Tabel Ope rasionalisasi Variabel (lanjutan)

\begin{tabular}{|c|c|c|c|c|}
\hline \multicolumn{5}{|c|}{ Variabel Kontrol } \\
\hline 1 & $\begin{array}{l}\text { Opini Auditor } \\
\text { (OPINION) }\end{array}$ & $\begin{array}{l}\text { Laporan yang diberikan } \\
\text { oleh akuntan publik atas } \\
\text { penilaian terhadap } \\
\text { kewajaran laporan } \\
\text { keuangan perusahaan }\end{array}$ & $\begin{array}{l}\text { Dummy variable. } \\
1=\text { qualified opinion, } 0= \\
\text { unqualified opinion }\end{array}$ & Carey \& Simnet (2006) \\
\hline 2 & $\begin{array}{l}\text { Ukuran perusahaan } \\
\text { (SIZE) }\end{array}$ & Skala perusahaan & Ln (Total Aset) & $\begin{array}{l}\text { Behn, Cho, \& Kang, } \\
(2008)\end{array}$ \\
\hline 3 & $\begin{array}{l}\text { Umur Perusahaan } \\
\text { (AGE) }\end{array}$ & Lama perusahaan berdiri & $\begin{array}{l}\text { Lama perusahaan berdiri } \\
\text { semenjak IPO / terdaftar di } \\
\text { Bursa Efek Indonesia (BEI) }\end{array}$ & Chen et al. (2008) \\
\hline 4 & $\begin{array}{l}\text { Tingkat Utang } \\
(\mathrm{LEV})\end{array}$ & $\begin{array}{l}\text { Jumlah pinjaman yang } \\
\text { dimiliki }\end{array}$ & $\frac{\text { Total liabilitas }}{\text { Total aset }}$ & $\begin{array}{l}\text { Johnson et al. (2002); } \\
\text { Jackson et al., (2008) }\end{array}$ \\
\hline 5 & Kerugian (LOSS) & $\begin{array}{l}\text { Kondisi keuangan } \\
\text { perusahaan }\end{array}$ & $\begin{array}{l}\text { Dummy variable. } \\
1=\text { laba bersifat negatif } / \text { rugi, } \\
0=\text { sebaliknya }\end{array}$ & $\begin{array}{l}\text { Choi et al. (2010); Dechow } \\
\text { \& Dichev (2002); Krauss } \\
\text { \& Zulch (2013) }\end{array}$ \\
\hline 6 & $\begin{array}{l}\text { Arus kas operasi } \\
\text { perusahaan }(\mathrm{CFO})\end{array}$ & $\begin{array}{lr}\text { Arus kas yang terkait } \\
\text { dengan } & \text { kegiatan } \\
\text { operasional perusahaan }\end{array}$ & $\frac{\text { Arus kas operasi }}{\text { total aset }}$ & $\begin{array}{l}\text { Dechow (1994); } \quad \text { Sloan } \\
(1996)\end{array}$ \\
\hline 7 & $\begin{array}{l}\text { Profitabilitas } \\
\text { (PERFORM) }\end{array}$ & $\begin{array}{l}\text { Kemampuan perusahaan } \\
\text { dalam memperoleh laba }\end{array}$ & $\frac{\text { laba bersih sebelum pajak }}{\text { total aset }}$ & Blandon \& Bosch (2017) \\
\hline 8 & $\begin{array}{l}\text { Pertumbuhan } \\
\text { perusahaan } \\
\text { (GROWTH) }\end{array}$ & $\begin{array}{l}\text { Peluang pertumbuhan } \\
\text { atas perusahaan dari } \\
\text { tahun ke tahun }\end{array}$ & $\frac{\left.\text { Sales }_{t}-\text { Sales }_{t-1}\right)}{\text { Sales }_{t-1}}$ & $\begin{array}{l}\text { Carey \& Simnett (2006); } \\
\text { Behn et al. (2008) }\end{array}$ \\
\hline 9 & $\begin{array}{l}\text { Reputasi } \quad \text { Kantor } \\
\text { Akuntan } \quad \text { Publik } \\
\text { (REPAFIRM) }\end{array}$ & $\begin{array}{l}\text { Reputasi / ukuran kantor } \\
\text { akuntan publik }\end{array}$ & $\begin{array}{l}\text { Dummy variable. } \\
1=\text { non-Big } 4 \text { dan } 0=\text { Big } 4\end{array}$ & Blandon \& Bosch (2017) \\
\hline
\end{tabular}




\section{Hasil dan Diskusi}

\section{Statistik Deskriptif}

Tabel 3 menggambarkan statistik deskriptif variabel penelitian. Dengan melihat pada tabel 3 yang menjelaskan statistik deskriptif atas data sampel yang dipergunakan, mengacu pada pengujian hipotesis 1 yang melihat pengaruh tenure KAP terhadap kualitas audit, tergambarkan bahwa pada variabel ABDA, nilai tertinggi dari keseluruhan sampel dimiliki oleh PT Indoritel Makmur Internasional Tbk (DNET) sebesar 8,452, sedangkan pada pengujian hipotes is 2 yang me lihat pengaruh tenure audit partner terhadap kualitas audit, dari keseluruhan sampel nilai ABDA tertinggi adalah sebesar 1,110 yang tergambarkan oleh PT Bakrie \& Brothers Tbk (BNBR). Dengan adanya gambaran ABDA yang tinggi maka dapat dikatakan bahwa adanya intervensi manajemen yang cukup besar dan membuat performa perusahaan berbeda dengan perusahaan-perusahaan lain di industri sejenis. Selain itu, juga terdapat beberapa perusahaan yang memiliki nilai ABDA yang hampir mendekati 0 mengindikasikan bahwa komponen akrual yang dimiliki oleh perusahaan telah disesuaikan dengan standar akuntansi yang berlaku. Sedangkan pada variabel FTenure, mayoritas dari data sampel cenderung memiliki tenure di kelompok 1 (tenure KAP 1 sampai 3 tahun) maupun di kelompok 2 (tenure KAP 4 hingga 6 tahun), sedangkan pada PTenure dari total keseluruhan sampel menggambarkan bahwa rata-rata tenure partner berada di 1 hingga 2 tahun.

Tabel 3. Statistik Desk riptif

\begin{tabular}{|c|r|r|r|r|r|r|r|r|r|}
\hline \multirow{2}{*}{ Variabel } & \multicolumn{4}{|c|}{ Hipotesis 1 (1.610 obs.) } & \multicolumn{5}{c|}{ Hi potesis 2 (1.128obs.) } \\
\cline { 2 - 10 } & Mean & Std. Dev & \multicolumn{1}{|c|}{ Min. } & Max. & Mean & Std. Dev & Min. & \multicolumn{1}{c|}{ Max. } \\
\hline $\begin{array}{c}\text { Variabel } \\
\text { Dependen }\end{array}$ & ABDA & 0,090 & 0,267 & 0,000 & 8,452 & 0,068 & 0,085 & 0,000 & 1,110 \\
\hline Variabel & FTENURE & 1,297 & 0,461 & 1,000 & 3,000 & - & - & - & - \\
\hline
\end{tabular}




\begin{tabular}{|c|c|c|c|c|c|c|c|c|c|}
\hline Inde penden & PTENURE & - & - & - & - & 1,716 & 0,800 & 1,000 & 4,000 \\
\hline \multirow{9}{*}{$\begin{array}{l}\text { Variabel } \\
\text { Kontrol }\end{array}$} & OPINION & 0,022 & 0,148 & 0,000 & 1,000 & 0,022 & 0,147 & 0,000 & 1,000 \\
\hline & SIZE & 14,353 & 1,782 & 6,803 & 20,330 & 14,518 & 1,774 & 6,804 & 19,296 \\
\hline & AGE & 15,468 & 7,190 & 1,000 & 64,000 & 15,648 & 7,226 & 1,000 & 64,000 \\
\hline & LEV & 0,693 & 4,445 & 0,000 & 163,23 & 0,717 & 5,295 & 0,003 & 163,230 \\
\hline & LOSS & 0,179 & 0,383 & 0,000 & 1,000 & 0,155 & 0,362 & 0,000 & 1,000 \\
\hline & PERFORM & 0,013 & 2,824 & $-112,920$ & 15,490 & $-0,006$ & 3,360 & $-111,922$ & 15,495 \\
\hline & CFO & 0,068 & 0,121 & $-1,070$ & 1,130 & 0,075 & 0,129 & $-1,073$ & 0,996 \\
\hline & GROWTH & 2,689 & 44,658 & $-8,910$ & 1380,920 & 1,818 & 27,638 & $-8,906$ & 619,408 \\
\hline & REPAFIRM & 0,605 & 0,489 & 0,000 & 1,000 & 0,568 & 0,496 & 0,000 & 1,000 \\
\hline
\end{tabular}

Keterangan: ABDA = Absolute Discretionary Accruals (proksi kualitas audit); FTENURE = lamanya hubungan antara kantor akuntan publik dengan klien; PTENURE = la manya hubungan antara partner auditor d engan klien; OPINION = laporan yang diberikan oleh akuntan publik atas penilaian terhadap ke wajaran laporan keuangan perusahaan; SIZE = ukuran perusahaan; $\mathrm{AGE}=$ la ma perusahaan berdiri; $\mathrm{LEV}=$ ju mlah pinja man yang dimiliki perusahaan; LOSS = tingkat kesehatan perusahaan; PERFORM = profitabilitas, kemampuan perusahaan dalam menghasilkan laba; GROWTH = peluang pertumbuhan perusahaan dari tahun ke tahun; REPAFIRM = reputasi kantor akuntan publik (Su mber: data yang diolah)

\section{Uji Hipotesis}

Untuk memastikan bahwa model yang digunakan sudah memenuhi standar BLUE (Best, Linear, Unbiased, Estimator), maka dilakukan uji asumsi klasik yang terdiri dari uji normalitas, uji multikolinearitas, uji heteroskedastisitas, dan uji autokorelasi. Pada pengujian normalitas, terdapat beberapa variabel yang melalui proses treatment untuk memastikan data yang dipergunakan sudah sesuai. Pada pengujian multikolinearitas, hasil menunjukkan bahwa tidak terdapat variabel yang menunjukkan gejala multikolinearitas ataupun tidak terdapat korelasi yang kuat antar variabel. Pada pengujian heteroskedastisitas dari kedua model menunjukkan adanya gejala heteroskedastisitas, maka dilakukan treatment dengan White's heteroskedasticity corrected standard errors atau dikenal dengan robust standard errors (Gujarati \& Porter, 2009) ataupun menggunakan model Generalized Least 
Square (GLS). Pada penelitian ini menggunakan regresi model Random Effect (RE) sehingga mengasumsikan bahwa data sudah bersifat BLUE. Sedangkan pada pengujian autokore lasi dengan menggunakan woolridge test menggambarkan bahwa dalam model regresi terbebas dari permasalahan autokorelasi. Lalu dalam menguji ketepatan model, didapatkan bahwa model regresi yang paling tepat adalah model Random Effect untuk kedua hipotesis, karena sesuai dengan karakteristik data yang digunakan, lalu agar data dapat diasumsikan bersifat BLUE dan dapat menghindari keterbatasan yang dimiliki model Fixed Effect (FE).

Tabel 4. Hasil Uji Hipotesis

\begin{tabular}{|c|c|c|}
\hline & \multicolumn{2}{|c|}{ ABDA } \\
\hline Variabel (Expected Sign) & Hipotesis 1 (FTEN URE) & Hipotesis 2 (PTENURE) \\
\hline FTENURE (+) & $\begin{array}{l}0,0123^{*} \\
(0,061)\end{array}$ & - \\
\hline PTENURE (+) & - & $\begin{array}{c}-0,0018 \\
(0,503)\end{array}$ \\
\hline OPINION (+) & $\begin{array}{l}0,0683 * \\
(0,065)\end{array}$ & $\begin{array}{c}0,0418 \\
(0,102)\end{array}$ \\
\hline SIZE (-) & $\begin{array}{c}-0,000004 \\
(0,222)\end{array}$ & $\begin{array}{c}-0,0000^{*} \\
(0,062)\end{array}$ \\
\hline AGE (-) & $\begin{array}{c}-0,0009 \\
(0,231)\end{array}$ & $\begin{array}{c}-0,0004 \\
(0,332)\end{array}$ \\
\hline LEVERAGE (+) & $\begin{array}{r}0,0075 \\
(0,387)\end{array}$ & $\begin{array}{l}0,0091 * \\
(0,075)\end{array}$ \\
\hline $\operatorname{LOSS}(+)$ & $\begin{array}{r}0,0201 \\
(0,136)\end{array}$ & $\begin{array}{c}-0,0028 \\
(0,779)\end{array}$ \\
\hline PERFORM (N/A) & $\begin{array}{l}0,0283 * * * \\
(0,000)\end{array}$ & $\begin{array}{l}0,0100 * * * \\
(0,000)\end{array}$ \\
\hline CFO (-) & $\begin{array}{c}-0,2836 * * * \\
(0,000)\end{array}$ & $\begin{array}{l}-0,1378 * * * \\
(0,000)\end{array}$ \\
\hline GROWTH (+) & $\begin{array}{l}0,0058^{* * *} \\
(0,043)\end{array}$ & $\begin{array}{c}0,0014 \\
(0,450)\end{array}$ \\
\hline REPAFIRM (+) & $-0,0044$ & $-0,0095$ \\
\hline
\end{tabular}




\begin{tabular}{|l|c|c|}
\hline & $(0,712)$ & $(0,162)$ \\
\hline cons & $\begin{array}{c}0,2070 \\
(0,000)\end{array}$ & $\begin{array}{l}0,1367 \\
(0,000)\end{array}$ \\
\hline Juml ah Observasi & 982 & 761 \\
\hline Juml ah Group & 223 & 158 \\
\hline R-sq Overall & 0,0702 & 0,0470 \\
\hline
\end{tabular}

Signifikansi : $* * * \alpha=1$ persen, ${ }^{* *} \alpha=5$ persen, ${ }^{*} \alpha=10$ persen; $p$-value (dalam tanda kurung)

Keterangan : $\mathrm{ABDA}=$ Absolute Discretionary Accruals (proksi kualitas audit); FTENURE = lamanya hubungan antara kantor akuntan publik dengan klien; PTENURE = lamanya hubungan antara partner auditor dengan klien; OPINION = laporan yang diberikan oleh akuntan publik atas penilaian terhadap ke wajaran laporan keuangan perusahaan; SIZE = ukuran perusahaan; $\mathrm{AGE}=$ la ma perusahaan berdiri; $\mathrm{LEV}=$ ju mlah pinja man yang dimiliki perusahaan; LOSS = tingkat kesehatan perusahaan; PERFORM = profitabilitas, kemampuan perusahaan dalam menghasilkan laba; GROWTH = peluang pertumbuhan perusahaan dari tahun ke tahun; REPAFIRM = reputasi kantor akuntan publik (Su mber: data yang diolah)

Tabel 4 menggambarkan hasil atas pengujian hubungan tenure KAP dengan kualitas audit yang diproks ikan melalui absolute discretionary accrual (ABDA). Tabel tersebut menunjukkan bahwa bahwa terdapat pengaruh negatif tenure KAP terhadap kualitas audit, sehingga menandakan semakin lama tenure KAP maka kualitas audit akan semakin menurun. Penelitian ini sejalan dengan penelitian Junaidi et al. (2012), Al-Thuneibat, Baker, Issa (2011) dan Panjaitan \& Chariri (2014). Berdasarkan pada teori keagenan, penggunaan jasa auditor eksternal yang merupakan realisasi atas monitoring cost menjadi dasar bagi perusahaan agar dapat menghasilkan laporan keuangan yang berkualitas, namun untuk mencegah adanya peningkatan cost maka beberapa perusahaan cenderung untuk terus mempertahankan auditornya dalam jangka waktu yang panjang. Sehingga pada akhirnya, penggunaan monitoring cost tersebut menjadi kurang efektif dikarenakan auditor yang ditunjuk oleh klien untuk melakukan proses audit pada akhirnya akan bergantung pada klien karena klien yang membayar jasa audit. Ketergantungan tersebut pada akhirnya akan membentuk suatu bonding effect, baik dilihat dari segi ekonomi maupun dari segi sosial, sehingga dapat menimbulkan hubungan yang bersifat excessive- 
familiarity (Chi \& Huang, 2005). Hubungan tersebut pada akhirnya akan memberikan hambatan bagi auditor untuk melaksanakan proses audit sesuai dengan kompetensinya dan mendasari segala penerimaan untuk menerima upaya dari klien untuk membuat perusahaan sesuai dengan ekspektasi dari klien tersebut.

Namun, apabila dilihat melalui penelitian yang menguji hubungan tenure audit partner terhadap kualitas audit dapat terlihat pada tabel 5 bahwa tidak adanya pengaruh antara tenure audit partner terhadap kualitas audit. Hasil ini mendukung penelitian Blandon \& Bosch (2017), Chi \& Huang (2005) dan Carey \& Simnett (2006). Menurut Chi \& Huang (20015) audit firm tenure merupakan peran kunci dalam menentukan kualitas audit,karena faktor learning effect dan excessive familiarity hanya memiliki pengaruh pada audit firm tenure dan tidak memiliki hubungan signifikan pada audit partner tenure. Selain itu, jika hanya terdapat perubahan audit partner dalam audit firm yang sama tidak akan memberikan pengaruh dapat learning experience karena informasi spesifik klien dapat diteruskan kepada partner selanjutnya. Lalu, pendapat tersebut didukung juga dengan Lennox et al. (2014) bahwa jika terdapat perusahaan partner tanpa adanya perusahaan KAP, maka metodologi, prosedur, dan perjanjian lainnya masih tetap sama. Sehingga jika hanya terdapat pergantian partner auditor, kualitas audit tidak dapat meningkat. Dan dalam penelitian Krauss \& Zulch (2013) mengatakan bahwa dengan jangka waktu audit yang panjang dapat meningkatkan pengetahuan spesifik mengenai klien dan dapat menurunkan tingkat independensi auditor. Sehingga kedua faktor yang memiliki pengaruh yang berkebalikan terhadap kualitas audit dan tidak terdapat faktor yang lebih dominan, akhirnya saling meniadakan satu sama lain dalam keseluruhan waktu hubungan antara auditor dengan klien.

Sehingga berdasarkan hasil kedua hipotesis, menunjukkan bahwa peran KAP memiliki peran utama dalam mempengaruhi kualitas audit, karena meskipun terdapat pembatasan jangka waktu pemberian jasa audit pada partner, selama pergantian partner masih dalam KAP yang sama maka 
informasi spesifik klien, metodologi, prosedur audit masih sama dan tidak dapat memberikan pengaruh pada kualitas audit yang dihasilkan. Sehingga agar kegiatan monitoring dapat berjalan lebih efektif dan dapat menghasilkan kualitas audit yang tinggi maka diperlukan pembatasan audit firm tenure.

\section{Uji Robustness}

Dengan adanya penerapan peraturan baru yakni Peraturan Pemerintah Republik Indonesia nomor 20 tahun 2015, tenure KAP tidak lagi dibatasi dan tenure audit partner diperpanjang menjadi 5 tahun, maka dilakukan uji robustness untuk melihat pengaruh tenure terhadap kualitas audit dengan periode tenure yang lebih panjang. Adapun hasil uji robustness dapat dilihat sebagai berikut: 
Tabel 5. Hasil Uji Robustness

\begin{tabular}{|c|c|c|}
\hline & \multicolumn{2}{|c|}{ ABDA } \\
\hline Variable (Expected sign) & Hipotesis 1 (FTEN URE) & Hipotesis 2 (PTENURE) \\
\hline FTenure (+) & $\begin{array}{l}0,0105^{* *} \\
(0,020)\end{array}$ & - \\
\hline PTenure (+) & - & $\begin{array}{c}0,0018 \\
(0,425)\end{array}$ \\
\hline OPINION (+) & $\begin{array}{l}0,0647 * * \\
(0,026)\end{array}$ & $\begin{array}{c}0,0331 \\
(0,152)\end{array}$ \\
\hline SIZE (-) & $\begin{array}{l}-0,000005 * * \\
(0,003)\end{array}$ & $\begin{array}{l}0,0000^{* * * *} \\
(0,005)\end{array}$ \\
\hline AGE (-) & $\begin{array}{c}-0,0006 \\
(0,125)\end{array}$ & $\begin{array}{l}-0,0002 \\
(0,463)\end{array}$ \\
\hline LEVERAGE (+) & $\begin{array}{l}0,0103 * * \\
(0,049)\end{array}$ & $\begin{array}{c}0,0030 \\
(0,520)\end{array}$ \\
\hline $\operatorname{LOSS}(+)$ & $\begin{array}{c}0,0012 \\
(0,883)\end{array}$ & $\begin{array}{l}-0,0157 * \\
(0,066)\end{array}$ \\
\hline PERFORM (N/A) & $\begin{array}{l}0,0090 * * * \\
(0,000)\end{array}$ & $\begin{array}{l}0,0062^{* * * *} \\
(0,006)\end{array}$ \\
\hline CFO (-) & $\begin{array}{l}-0,1881 * * * \\
(0,000)\end{array}$ & $\begin{array}{l}-0,1251 * * * \\
(0,000)\end{array}$ \\
\hline GROWTH (+) & $\begin{array}{l}0,0034 * * \\
(0,040)\end{array}$ & $\begin{array}{l}0,0032^{*} \\
(0,070)\end{array}$ \\
\hline REPAFIRM (+) & $\begin{array}{c}-0,0136 * * \\
(0,047)\end{array}$ & $\begin{array}{l}-0,0079 \\
(0,158)\end{array}$ \\
\hline _cons & $\begin{array}{c}0,1444 \\
(0,000)\end{array}$ & $\begin{array}{l}0,1101 \\
(0,000)\end{array}$ \\
\hline Juml ah Obser vasi & 1.410 & 922 \\
\hline Jumlah Group & 207 & 131 \\
\hline R-s q Overall & 0,0546 & 0,0491 \\
\hline
\end{tabular}

Signifikansi : $* * * \alpha=1$ persen, ${ }^{* *} \alpha=5$ persen, ${ }^{*} \alpha=10$ persen; $p$-value (dalam tanda kurung)

Keterangan $: \mathrm{ABDA}=$ Absolute Discretionary Accruals (proksi kualitas audit); FTENURE = lamanya hubungan antara kantor akuntan publik dengan klien; PTENURE = la manya hubungan antara partner auditor dengan klien; OPINION = laporan yang diberikan oleh akuntan publik atas penilaian terhadap kewajaran laporan keuangan 
perusahaan; SIZE = ukuran perusahaan; $\mathrm{AGE}=$ la ma perusahaan berdiri; $\mathrm{LEV}=$ ju mlah pinja man yang dimiliki perusahaan; LOSS = tingkat kesehatan perusahaan; PERFORM = profitabilitas, kemampuan perusahaan dalam menghasilkan laba; GROWTH = peluang pertumbuhan perusahaan dari tahun ke tahun; REPAFIRM = reputasi kantor akuntan publik (Su mber: data dio lah)

Tabel 6. Hasil Uji Robustness 3

\begin{tabular}{|c|c|c|c|c|}
\hline Paired & Obs & Mean & Std. Err. & Std. Dev \\
\hline ABDA 1 (tenure 1 ) & 84 & 0,0672 & 0,0087 & 0,0794 \\
\hline ABDA 3 (tenure 3 ) & 84 & 0,0593 & 0,0067 & 0,6111 \\
\hline diff & 84 & 0,0079 & 0,0108 & 0,0989 \\
\hline Ho: mean $($ diff $)<0$ & \multicolumn{2}{|c|}{ Ho : mean (diff) $!=0$} & \multicolumn{2}{|c|}{ Ho : mean $($ diff $)>0$} \\
\hline 0,7663 & \multicolumn{2}{|c|}{0,4673} & \multicolumn{2}{|c|}{0,2337} \\
\hline
\end{tabular}

Signifikansi : $* * * \alpha=1$ persen, $* * \alpha=5$ persen, $* \alpha=10$ persen

Keterangan : ABDA = absolute discretionary accruals sebagai proksi kualitas audit. (Sumber: data diolah)

Tabel 5 menunjukkan hasil uji robustness dengan periode 2008 hingga 2018, sehingga data pengujian sudah menggunakan data perusahaan sebelum dan sesudah Peraturan Pemerintah Republik Indonesia nomor 20 tahun 2015 diterapkan. Hasil uji robustness pada tabel 5 memperkuat hasil uji utama, baik pengujian pada tenure KAP dan tenure partner audit masih menggambarkan hasil yang serupa dengan penelitian utama yaitu tenure KAP memiliki pengaruh negatif terhadap kualitas audit dan tenure partner audit tidak memiliki pengaruh terhadap kualitas audit.

Kemudian pada uji robustness pada tabel 6 menunjukkan hasil uji beda $t$-test pada kualitas audit pada saat partner tenure 1 dan 3, dengan periode 2008 hingga 2014. Hasil menunjukkan bahwa tidak terdapat perbedaan yang signifikan pada kualitas audit saat tenure yang berbeda. Sehingga hasil uji robustness ini juga mendukung hasil uji utama bahwa audit partner tenure tidak memiliki pengaruh yang signif ikan terhadap kualitas audit.

\section{Kesimpulan, Keterbatasan, Saran dan Implikasi Praktis}

\section{Kesimpulan}


Penelitian ini bertujuan untuk menganalisis pengaruh audit tenure baik pada KAP maupun audit partner terhadap kualitas audit. Penelitian ini dilakukan dengan model regresi linear Random Effect. Pengujian pengaruh audit tenure terhadap kualitas audit menggunakan variabel dependen yaitu kualitas audit dengan proksi absolute accrual discretionary, dua variabel independen yaitu audit firm tenure dan audit partner tenure dan variabel kontrol yang terdiri dari opini, ukuran perusahaan, umur perusahaan, tingkat utang, kerugian, arus kas operasi, profitabilitas, pertumbuhan, dan reputasi KAP, pada periode 2008 hingga 2014 sebagai tahun Peraturan Menteri Keuangan No. 17/PMK.01/2008 mengenai pembatasan masa pemberian jasa audit diberlakukan. Hasil penelitian ini menunjukkan pengaruh negatif audit firm tenure terhadap kualitas audit yang diproksikan dengan absolute discretionary accrual yang sejalan dengan penelitian Junaidi et al. (2012), Al-Thuneibat et al. (2011), dan Panjaitan \& Chariri (2014). Sedangkan audit partner tenure tidak memiliki pengaruh terhadap kualitas audit yang juga sejalan dengan penelitian Blandon \& Bosch (2017), Krauss \& Zulch (2013), serta Carey \& Simnett (2006). Hasil penelitian juga didukung dengan dua uji robustness, dengan periode 2008 hingga 2018 dan uji beda untuk audit partner tenure, yang menggambarkan hasil yang serupa dengan penelitian utama. Maka dapat disimpulkan, bahwa audit firm tenure memiliki peran kunci untuk meningkatkan kualitas audit.

\section{Keterbatasan}

Pertama, nilai $R$-square dari kedua model regresi dalam pengujian utama masih tergolong cukup kecil. Adapun nilai $R$-square dalam uji robustness untuk melihat hubungan antara audit tenure terhadap kualitas audit pada periode 2008-2018 juga menggambarkan nilai yang kecil. Kedua, penerapan tenure partner di Indonesia yang terhitung relatif singkat sehingga sulit untuk melihat perbedaan dalam periode hanya 3 tahun saja. Ketiga, periode yang terbatas juga memberikan hambatan dalam penelitian ini untuk melihat apakah terjadi perbedaan selama perpanjangan masa tenure KAP 
maupun partner dalam penerapan Peraturan Pemerintah Republik Indonesia nomor 20 tahun 2015. Sehingga hasil yang tergambar belum dapat dianalisis lebih dalam.

\section{Saran}

Berdasarkan keterbatasan yang telah dijabarkan, maka untuk peneliti selanjutnya dapat menggunakan ataupun menambahkan variabel lain yang dapat menjelaskan variabel dependen. Kemudian, dapat memperpanjang periode penelitian untuk dapat melihat pengaruh dari audit tenure terhadap kualitas audit dengan berdasarkan pada Peraturan Pemerintah Republik Indonesia No 20 tahun 2015. Serta dapat mempertimbangkan untuk membandingkan pengaruh tenure pada KAP dengan nama foreign affiliation dan dengan nama lokal terhadap kualitas audit.

\section{Implikasi}

Berdasarkan hasil penelitian ini dapat memberikan implikasi praktis bagi berbagai pihak. Bagi pembaca atau akademisi dapat menambah informasi bahwa audit firm tenure merupakan peran utama yang mempengaruhi kualitas audit dan dapat dijadikan referensi untuk melanjutkan penelitian dengan variabel terkait. Lalu bagi investor dapat menjadikan informasi ini sebagai bahan pertimbangan untuk mengambil keputusan investasi pada perusahaan yang memiliki audit firm tenure yang panjang. Kemudian bagi perusahaan dapat menjadi bahan pertimbangan untuk membatasi masa audit firm tenure meskipun pada Peraturan Pemerintah Republik Indonesia nomor 20 tahun 2015 sudah tidak membatasi masa pemberian jasa audit pada KAP karena semakin lama auditfirm tenure maka kualitas audit akan menurun. Bagi regulator khususnya Menteri Perekonomian dan Keuangan, diperlukan peninjauan kembali atas penerapan Peraturan Pemerintah Republik Indonesia nomor 20 tahun 2015 yang meniadakan batasan terhadap auditfirm dalam memberikan jasa audit dan memperpanjang tenure partner. Sebab, dengan mempertimbangkan pada hasil penelitian di atas yang juga mendukung 
penelitian - penelitian terdahulu, bahwa audit firm tenure yang menjadi kunci utama dalam menjaga dan meningkatkan kualitas audit.

\section{Daftar Pus taka}

Achmad, T., Rus min, Neilson, J. \& Tower, G. (2009). The In iquitous Influence of Family Ownership Structures on Corporate Performance. The Journal of Global Business Issues, 3 (1), 41-48.

Al-Thuneibat, A.A., Al Issa, R.T.I. and Baker, R.A.A. (2011). Do Audit Tenure and Firm Size Contribute to Audit Quality?: Empirical Evidence from Jordan. Managerial Auditing Journal, 26(4), 317-334.

Behn, B., Choi, J.H., \& Kang, T. (2008). Audit Quality and Properties of Analyst Earnings Forecasts. The Accounting Review, 83(2), 327-349.

Blandon, J. G., \& Bosch, J. M. A. (2017). The Interaction Effects of Firm and Partner Tenure on Audit Quality. Accounting and Business Research, 47(7), 810-830.

Carcello, J. V., \& Nagy, A. L. (2004). Audit Firm Tenure and Fraudulent Financial Reporting. Auditing: A Journal of Practice \& Theory, 23(2), 55-70.

Carey, P. \& Simnett, R. (2006). Audit Partner Tenure and Audit Quality. The Accounting Review, 81(3), 653676.

Chen, C. Y., Lin, C. J. \& Lin, Y. C. (2008). Audit Partner Tenure, Audit Firm Tenure, And Discretionary Accruals: Does Long Auditor Tenure Impair Earnings Quality?. Contemporary Accounting Research, 25(2), 415-445

Chi, W. \& Huang, H. (2005). Discretionary accruals, audit-Firm tenure and audit-Partner tenure: Empirical evidence from Taiwan. Journal of Contemporary Accounting \& Economics I, 65-92.

Choi, J.H., Kim, J.B. \& Zang, Y. (2010). Do Abnormally High Audit Fees Impair Audit Quality?. Auditing: A Journal of Practice \& Theory, 29(2), 115-140.

DeAngelo, L. E. (1981). Auditor Size And Audit Quality. Journal of Accounting \& Economics, 3(3), $183-199$.

Dechow, P. M. (1994). Accounting Earnings And Cash Flows As Measures Of Firm Performance: The Role Of Accounting Accruals. Journal of Accounting and Economics, 18(1), 3-42.

Dechow, P. M., Sloan, R. G., \& Sweeney, A. P. (1995). Detecting Earnings Management. The Accounting Review, 70(2), 193-225.

Dechow, P. \& Dichev, I. (2002). The Quality Of Accruals And Earnings. The Accounting Review, 77, $35-59$.

Defond, M. L. \& Subramanyam, K. R. (1998). Auditor Changes And Discretionary Accruals. Journal of Accounting \& Economics, 25(1), 35-68.

Dinuka, V. K. \& Zulaikha (2014). Analisis Pengaruh Audit Tenure, Ukuran KAP, dan Diversifikasi Geografis terhadap Manajemen Laba. Diponegoro Journal of Accounting, 3(3), 1.

Geiger, M.A. \& Raghunandan K. (2002). Auditor Tenure and Audit Reporting Failu res. A Journal of Practice \& Theory, 21(1), 67-78.

Godfrey, J. M., Hodgson, A., Tarca, A., Hamilton, J. \& Holmes S. (2010). Accounting Theory (7th ed.). Milton: John Wiley \& Sons.

Gujarati, D.N. \& Porter, D.C. (2009). Basic Econo metrics (5th ed.). New York: Mc Graw Hill.

Healy, P. (1985). The Impact Of Bonus Schemes On The Selection Of Accounting Principles. Journal of

Accounting and Economics, 7, 85-107.

Jackson, A. B., Moldrich, M., \& Roebuck P. (2008). Mandatory Audit Firm Rotation And Audit Quality. Managerial Auditing Journal, 23(5), 420-437.

Jensen, M. C., \& Meckling, W. H. (1976). Theory Of The Firm: Managerial Behavior, Agency Costs And Ownership Structure. Journal of Financial Economics, 3(4), 305-360.

Johnson, V. E., Khurana, I.K. \& Reynolds, J. K. (2002). Audit-firm tenure and the quality of financial reports.

Contemporary Accounting Research, 19(4), 637-660.

Keune, M. B. \& Johnstone, K. M. (2012). Materiality Judgments And The Resolution Of Detected Mis statements: The Role Of Managers, Auditors, And Audit Committees. The Accounting Review, 87(5), 1641-1677. 
Knapp, M. (1991). Factors That Audit Co mmittees Use As Surrogates For Audit Quality. Auditing: A Journal of Practice \& Theory, 10(1), 35-52.

Krauss, P. \& Zülch, H. (2013). The Relation of Auditor Tenure to Audit Quality: Empirical Evidence from the German Audit Market. Journal of Governance and Regulation, 2(1), 27-43.

Lennox, C.S., Wu, X., Zhang, T. (2014). Does Mandatory Rotation Of Audit Partners Improve Audit Quality?. The Accounting Review, 89(5), 1775-1803.

Mansi, S. A., Maxwell, W. F., \& Miller, D. P. (2004). Does auditor quality and tenure matter to investors? Evidence from The Bond Market. Journal of Accounting Research, 42(4), 755-793.

Nasser, A. T. A., Wahid, E. A., Nazri, S.N.F.S.M., Hudaib, M. \& (2006). Auditor-Client Relationship: The Case of Audit Tenure and Auditor Switching In Malaysia. Managerial Auditing Journal, 21(7), 724-737.

Panda, B. \& Leepsa, N.M. (2017). Agency Theory: Review of Theory and Evidence on Problems and Perspectives. Indian Journal of Corporate Governance, 10 (I), 74-95.

Panjaitan, C.M. \& Chariri, A. (2014). Pengaruh Audit Tenure, Ukuran KAP, dan Spesialisasi Auditor Terhadap Kualitas Audit. Diponegoro Journal of Accounting, 3(3), 1-12.

Siregar, S. V., A maru llah, F., Wibowo, A. \& Anggraita, V. (2012). Audit tenure, auditor rotation, and audit quality: The case of Indonesia. Asian Journal of Business and Accounting, 5(1), 55-74. 